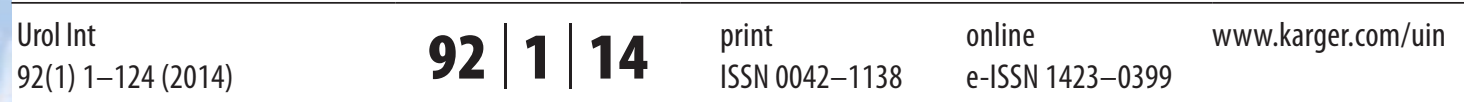
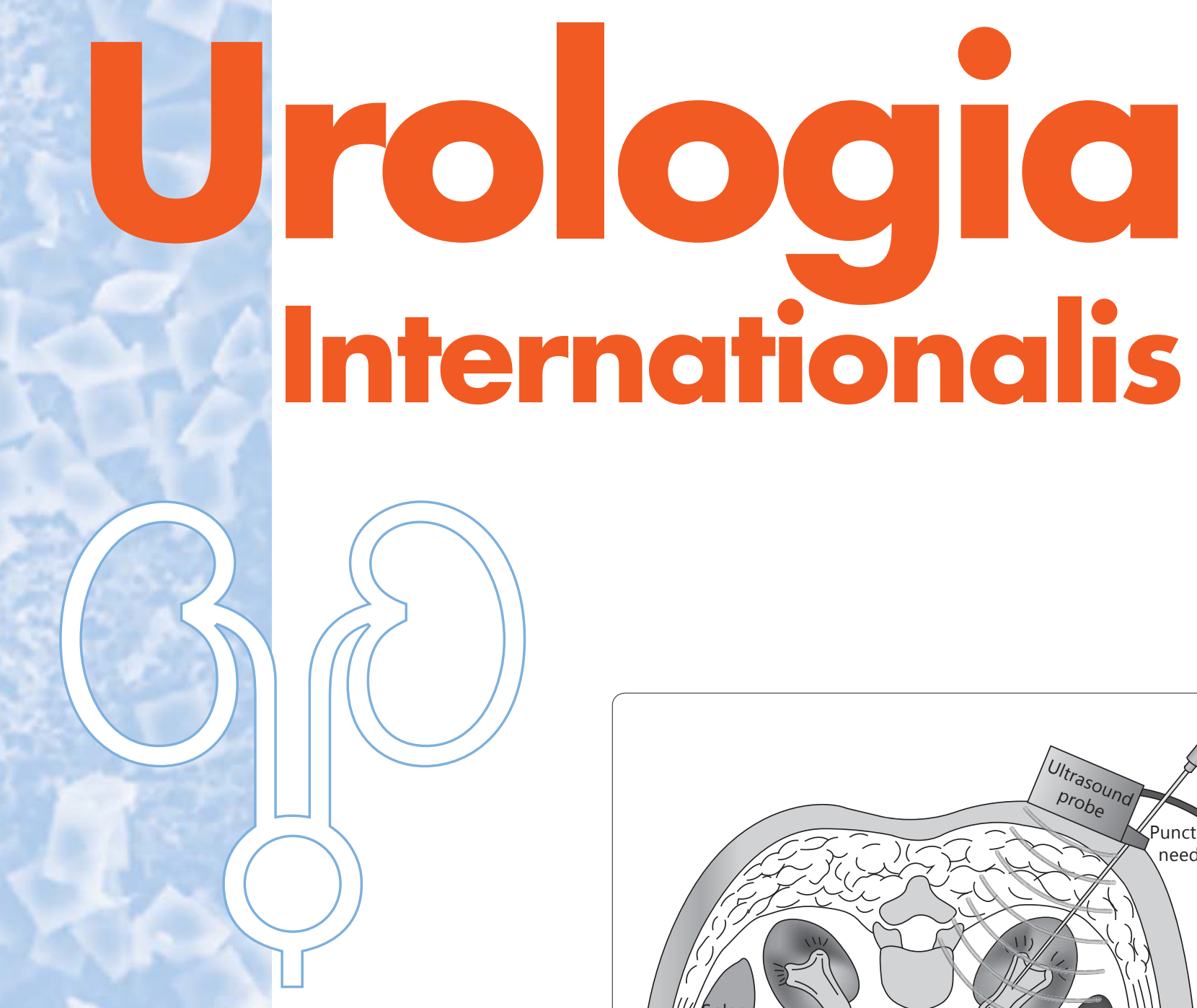

S. Karger

Medical and Scientific Publishers $\mathrm{KARC}$ E R

Basel · Freiburg · Paris .

London · New York · Chennai .

New Delhi · Bangkok · Beijing .

Shanghai $\cdot$ Tokyo $\cdot$ Kuala Lumpur

Singapore $\cdot$ Sydney
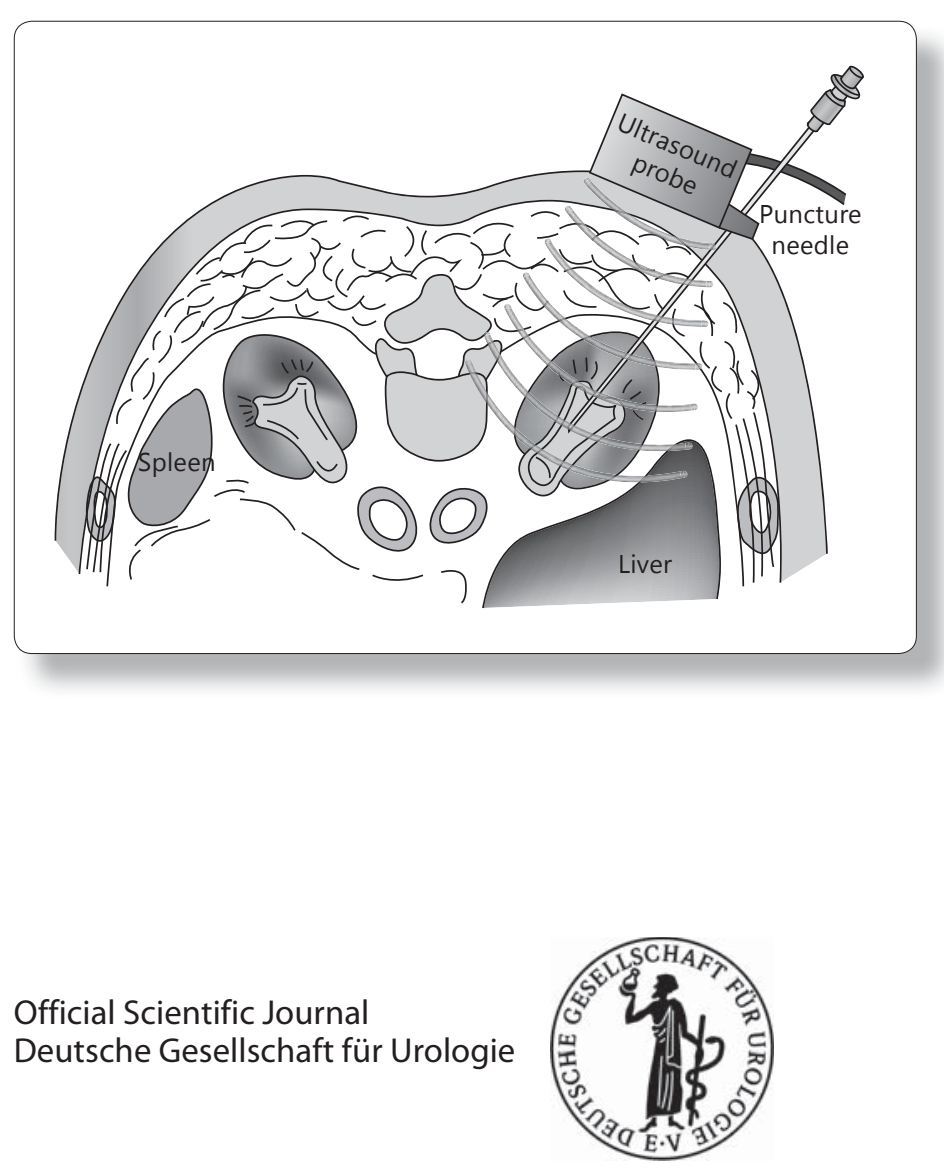


\section{ANDREAS VESALIUS}

\section{The Fabric \\ of the Human Body}

\section{An Annotated Translation of the 1543 and 1555 Editions of}

"De Humani Corporis Fabrica" by

\section{DANIEL H. GARRISON \\ MALCOLM H. HAST}

with contributions by Vivian Nutton and Nancy Siraisi

For the first time ever, both editions of Andreas Vesalius' masterpiece "De Humani Corporis Fabrica" are accessible in the English language. They were critically compared and published in a modern layout transforming the Renaissance anatomical atlas for the 21st-century reader. More than 5,000 annotations cover anything from antique sources over Galenic references to the medical and cultural background of Vesalius' time. Also included are Vesalius' handwritten notes for a never published third edition.

To enable the reader and medical student to really study Vesalius' woodcut illustrations, the images were digitally enhanced and often enlarged to feature his painstaking work of marking each pertinent anatomical part with characters. All over Vesalius' descriptive text, the standard Latin Nomina Anatomica and Terminologia Anatomica provide the reader with the modern medical terminology.

Vesalius, A., The Fabric of the Human Body

An Annotated Translation of the 1543 and 1555 Editions of

"De Humani Corporis Fabrica Libri Septem" by

D.H. Garrison and M.H. Hast

CXX + 1338 p., 340 fig., in two volumes, hard cover, with slip case, 2014 $315 \times 435 \mathrm{~mm} / 12 \times 17 ", 16 \mathrm{~kg} / 35 \mathrm{lbs}$

CHF 1,500.- / EUR 1,250.- / USD 1,650.00

ISBN 978-3-318-02246-9

\section{www.karger.com}

Postage and handling included

VAT \& import taxes excluded, no right to return

Prices subject to change, EUR price for Germany, USD price for USA and Latin America only 


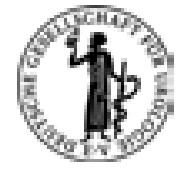

Official Scientific Journal of the Deutsche Gesellschaft für Urologie/ German Society of Urology

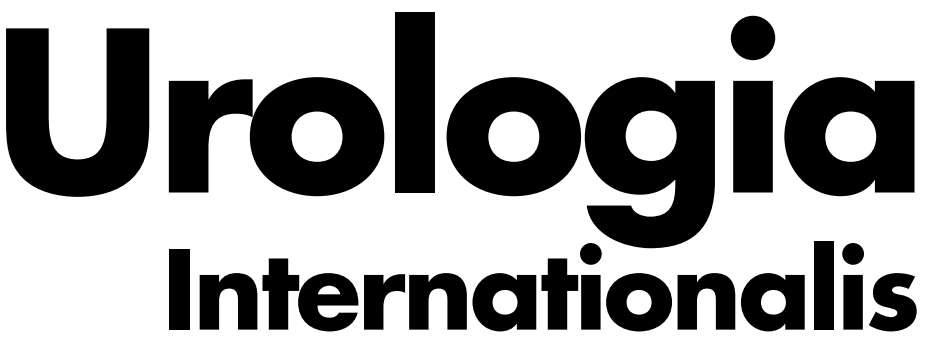

Founded 1955 by G. Peter A. Narath and Heinrich Heusser Successors: G. Mayor (1968-1987); D. Hauri (1988-2005)

\section{Editorial Committee}

S. Egawa, Tokyo

Ph. Jaeger, Uxbridge

V. Mirone, Napoli

R. Mundy, London

J. Nordling, Herlev

M. Porena, Perugia
P. Rigatti, Milano

H. Rübben, Essen

A. Stenzl, Tübingen

Y. Sun, Shanghai

G. Watson, Eastbourne

W. Weidner, Giessen

\section{Board of Reviewing Editors}

P. Albers, Düsseldorf

G.L. Andriole, St. Louis

W. Artibani, Verona

M. Babjuk, Prag

G. Baretton, Dresden

P. Bassi, Roma

G. Bogaert, Leuven

N.N.P. Buchholz, London

M. Burger, Würzburg

P. Caione, Roma

T. Concepcion Masip, La Laguna, Tenerife

E. Costantini, Perugia

P. Dahm, Gainesville

M. Fisch, Hamburg

P. Fornara, Halle

B. Frea, Udine

M. Froehner, Dresden

S. Füssel, Dresden

J.P. Gearhart, Baltimore

T. Hanus, Prague

J. Heesakkers, Nijmegen

W. Horninger, Innsbruck

G. Janetschek, Salzburg

M.M. Karram, Cincinnati
S. Kliesch, Münster J.N. Krieger, Seattle

M. Lazzeri, Firenze

S. Madersbacher, Wien

V.R. Marshall, Adelaide

A. Martin Morales, Malaga

M. Mas, La Laguna, Tenerife

L. Mearini, Perugia

E. Montanari, Milano

G. Morgia, Catania

G. Nicita, Firenze

R.T.D. Oliver, London

C. Protzel, Rostock

P. Radziszewski, Warsaw

P.N. Schlegel, New York

B.J. Schmitz-Dräger, Fürth

S. Siracusano, Trieste

N. Sofikitis, Ioannina

W.L. Strohmaier, Coburg

H.-G. Tiselius, Stockholm

L. Türkeri, Istanbul

F. Verrey, Zürich

F. vom Dorp, Essen

F. Wagenlehner, Giessen

A. Zucchi, Perugia 


\section{Urologia

\section{Submission}

Manuscripts written in English should be submitted using the online submission website at:

\section{www.karger.com/uin}

or as e-mail attachment (the preferred word-processing package is MS-Word) to the Editorial Office:

\section{uin@karger.ch}

S. Karger AG

Editorial Office 'Urologia Internationalis'

P.O. Box

$\mathrm{CH}-4009$ Basel (Switzerland)

Tel. +4161306 1424

Fax +4161306143

The manuscripts should be accompanied by a signed cover letter adressing the points below. A signed copyright transfer statement is required upon acceptance (please see submission website).

\section{Conditions}

All manuscripts are subject to peer review. Manuscripts are received with the explicit understanding that they are no under simultaneous consideration by any other publication. Submission of an article for publication implies the transfer of the copyright from the author to the publisher upon acceptance. Accepted papers become the permanent property of Urologia Internationalis and may not be reproduced by any means, in whole or in part, without the written consent of the publisher. It is the author's responsibility to obtain permission to reproduce illustrations, tables, etc. from other publications.

\section{Cover Letter}

It must include statements on the following points:

1. All authors have made a significant contribution to the findings and methods in the paper.

2. All authors have read and approved the final draft.

3. Financial or commercial interest must be acknowledged.

4. The work has not already been published and has not been submitted simultaneously to any other journal.

5. The corresponding author takes on the above responsibilities with his/her signature.

\section{Plagiarism Policy}

Whether intentional or not, plagiarism is a serious violation. We define plagiarism as a case in which a paper re produces another work with at least $25 \%$ similarity and without citation.

If evidence of plagiarism is found before/after acceptance or after publication of the paper, the author will be offered a chance for rebuttal. If the arguments are not found to be satisfactory, the manuscript will be retracted and the author sanctioned from publishing papers for a period to be determined by the responsible Editor(s).

\section{Arrangement}

Title page: The first page of each paper should indicate the title, the authors' names, the institute where the work was conducted.

In addition, the following should be put on the title page: 1. Short title for use as running head

2. A list of 3-10 key words for indexing purposes is essential

3. Corresponding author: One of the authors has to be indicated as the corresponding author. The full name and complete mailing address, e-mail address, as well as phone and fax numbers of that individual to whom correspondence, proofs, and requests for reprints should be addressed, must be given at the bottom of the title page.

Abstract: Each paper must have a structured abstract (Introduction, Materials and Methods, Results and Conclusions) of up to 20 lines (approximately 150 words). Abstracts of case reports need not be structured.
Footnotes: Avoid footnotes. When essential, they are numbered consecutively and typed at the foot of the appropriate page.

Tables and illustrations: Tables and illustrations (both numbered in Arabic numerals) should be prepared on separate pages. Tables require a heading and figures a legend, also prepared on a separate page. For technical reasons, figures with a screen background should not be submitted. When possible, group several illustrations on one block for reproduction (max size $180 \times 223 \mathrm{~mm}$ ) or provide crop marks. Electronically submitted b/w half-tone and color illustrations must have a final resolution of $300 \mathrm{dpi}$ after scaling, line drawings one of 800-1,200 dpi. Figure files must not be embedded in a document file but submitted separately (for detailed instructions, see http://www.karger.com/uin).

Case Reports should include the most important clinical details and not exceed 1,000 words. One table and two figures may be included. References should be limited to ten

Letters to the Editor must include matters of interest to urologists and not exceed 500 words.

Color illustrations

Online edition: Color illustrations are reproduced free of charge. In the print version, the illustrations are reproduced in black and white. Please avoid referring to the colors in the text and figure legends.

Print edition: Up to 6 color illustrations per page can be integrated within the text at CHF 800.- per page.

References: In the text identify references by Arabic numerals [in square brackets]. Material submitted for publication but not yet accepted should be noted as [unpublished data] and not be included in the reference list. The list of references should include only those publications which are cited in the text. Do not alphabetize; number references in the order in which they are first mentioned in the text. The surnames of the authors followed by initials should be given. There should be no punctuation other than a comma to separate the authors. Preferably, please cite all authors. Abbreviate journal names according to the Index Medicus system. Also see International Committee of Medical Journal Editors: Uniform requirements for manuscripts submitted to biomedical journals (www.icmje.org).

Examples

(a) Papers published in periodicals: Sun J, Koto H, Chung KF. Interaction of ozone and allergen challenges on bronchial responsiveness and inflammation in sensitised guinea pigs. Int Arch Allergy Immunol 1997;112:191-195.

(b) Papers published only with DOI numbers:

Theoharides TC, Boucher W, Spear K: Serum interleukin-6 reflects disease severity and osteoporosis in mastocytosis patients. Int Arch Allergy Immunol DOI: $10.1159 / 000063858$.

(c) Monographs: Matthews DE, Farewell VT: Using and Understanding Medical Statistics, ed 3, revised. Basel, Karger, 1996.

(d) Edited books: Parren PWHI, Burton DR: Antibodies against HIV-1 from phage display libraries: Mapping of an immune response and progress towards antiviral immunotherapy; in Capra JD (ed): Antibody Engineering. Chem Immunol. Basel, Karger, 1997, vol 65, pp 18-56.

Reference Management Software: Use of EndNote is recommended for easy management and formatting of citations and reference lists.

\section{Digital Object Identifier (DOI)}

S. Karger Publishers supports DOIs as unique identifiers for articles. A DOI number will be printed on the title page of each article. DOIs can be useful in the future for identifying and citing articles published online without volume or issue information. More information can be found at www.doi.org

\section{Supplementary Material}

Supplementary material is restricted to additional data that are not necessary for the scientific integrity and conclusions of the paper. Please note that all supplementary files will undergo editorial review and should be submitted together with the original manuscript. The Editors reserve the right to limit the scope and length of the supplementary material. Supplementary material must meet production quality standards for Web publication without the need for any modification or editing. In general, supplementary files should not exceed $10 \mathrm{Mb}$ in size. All figures and tables should have titles and legends and all files should be supplied separately and named clearly. Acceptable files and formats are: Word or PDF files, Excel spreadsheets (only if the data cannot be converted properly to a PDF file), and video files (.mov, .avi, .mpeg).

\section{Author's Choice ${ }^{\mathrm{TM}}$}

Karger's Author's Choice ${ }^{\mathrm{TM}}$ service broadens the reach of your article and gives all users worldwide free and full access for reading, downloading and printing at www.karger.com. The option is available for a one-time fee of $\mathrm{CHF}$ $3,000 .-$, which is a permissible cost in grant allocation. More information can be found at www.karger.com/authors_choice.

\section{NIH-Funded Research}

The U.S. National Institutes of Health (NIH) mandates under the NIH Public Access Policy that final, peer-reviewed manuscripts appear in its digital database within 12 months of the official publication date. As a service to authors, Karger submits the final version of your article on your behalf to PubMed Central. For those selecting our premium Author's Choice ${ }^{\mathrm{TM}}$ service, we will send your article immediately upon publishing, accelerating the accessibility of your work without the usual embargo. More details on NIH's Public Access Policy is available at http://publicaccess.nih.gov/FAQ.htm\#al

\section{Self-Archiving}

Karger permits authors to archive their pre-prints (i.e. prerefereeing) or post-prints (i.e. final draft post-refereeing) on their personal or institution's servers, provided the following conditions are met: Articles may not be used for commercial purposes, must be linked to the publisher's version, and must acknowledge the publisher's copyright. Authors selecting Karger's Author's Choice ${ }^{\mathrm{TM}}$ feature, how ever, are also permitted to archive the final, published version of their article, which includes copyediting and design improvements as well as citation links.

\section{Page Charges}

There are no page charges for original papers of 3 or fewer printed pages $(3,000$ words including tables, illustrations and references) or for case reports with 2 or fewer printed pages. Each extra complete or partial page is charged to the author at CHF 325.-. The allotted size of a paper is equal to approx. 8 manuscript pages double-spaced (including tables, illustrations and references). The inability to pay charges for extra pages will not prejudice publication of the paper. This will be decided by the Editors.

\section{Proofs}

Pdf proofs will be sent to the corresponding author and should be returned with the least possible delay.

\section{E-pub First}

All articles are published electronically ahead of print with a DOI number and are supplemented later with the definite reference of the printed version. The articles become available immediately after the authors' approval to publication, with the added advantage of being citable much earlier than in print. Authors can influence the time of appearance by promptly returning the proofs.

\section{Reprints}

Order form and price list is sent with the pdf proofs. Orders submitted after the issue is printed are subject to considerably higher prices.

\section{KARGER}

E-Mail karger@karger.com www.karger.com
(C) 2014 S. Karger AG, Basel 


\section{Urologia \\ Internationalis}

ISSN Print Edition: 0042-1138

ISSN Online Edition: 1423-0399

Journal Homepage: www.karger.com/uin

Publication Data: Urologia Internationalis is published 8 times a year. Volumes 92-93, each with 4 issues, appear in 2014.

Copyright: (c) 2014 S. Karger AG, Basel (Switzerland) All rights reserved. No part of this publication may be translated into other languages, reproduced or utilized in any form or by any means, electronic or mechanical including photocopying, recording, microcopying, or by any information storage and retrieval system, without permission in writing from the publisher or, in the case of photocopying, direct payment of a specified fee to the Copyright Clearance Center.

Disclaimer: The statements, opinions and data contained in this publication are solely those of the individual authors and contributors and not of the publisher and the editor(s). The appearance of advertisements in the journal is not a warranty, endorsement, or approval of the products or services advertised or of their effectiveness, quality or safety. The publisher and the editor(s) disclaim responsibility for any injury to persons or property resulting from any ideas, methods, instructions or products referred to in the content or advertisements.
Subscription Rates: Subscriptions run for a full calendar year. Prices are given per year. Personal subscription:

Print or Online

CHF 2182.-

EUR 1788.-

USD 2182.00

Print+Online combined CHF 2278.-

EUR 1866.-

USD 2278.00

postage and handling (added to print and print+online)

CHF 59.20 Europe, CHF 86.40 Overseas

EUR 48.-

USD 78.40

Institutional subscription:

Print or Online

Print+Online combined

CHF 4362.

EUR 3576.-

CHF 4798.-

postage and handling (added to print and print+online)

CHF 74.- Europe, CHF 108.- Overseas

EUR 60.-

USD 98.00

Discount subscription prices:

National and international urological societies.
Back Volumes and Single Issues: Information on availability and prices of single print issues and print or electronic back volumes can be obtained from Customer Service atservice@karger.com.

Bibliographic Indices: This journal is regularly listed in bibliographic services, including Current Contents ${ }^{\circledR}$ and PubMed/MEDLINE.

Photocopying: This journal has been registered with the Copyright Clearance Center (CCC), as indicated by the code appearing on the first page of each article. For readers in the US, this code signals consent for copying of articles for personal or internal use, or for the personal or internal use of specific clients, provided that the stated fee is paid per copy directly to

Copyright Clearance Center Inc.

222 Rosewood Drive

Danvers, MA 01923 (USA)

A copy of the first page of the article must accompany payment. Consent does not extend to copying for general distribution, for promotion, for creating new works, or for resale. In these cases, specific written permission must be obtained from the copyright owner,

S. Karger AG, P.O. Box

CH-4009 Basel (Switzerland).

\begin{tabular}{|c|c|c|c|}
\hline Subscription Orders: & or further Karger offices & USA & Karger China \\
\hline \multirow[t]{2}{*}{$\begin{array}{l}\text { Orders can be placed at agencies, } \\
\text { bookstores, directly with the Publisher }\end{array}$} & or representatives: & S. Karger Publishers, Inc. & West/5F, China Life Tower \\
\hline & Germany & P.O. Box 529 & $\begin{array}{l}\text { No.16, Chao Wai street } \\
\text { Chaoyang District }\end{array}$ \\
\hline S. Karger AG & S. Karger GmbH & Unionville, CT 06085 & Beijing 100020 \\
\hline Medical and Scientific Publishers & Postfach & USA & China \\
\hline Allschwilerstrasse 10 & 79095 Freiburg & Toll free: +18008285479 & $\mathrm{t}: \quad+861058771408$ \\
\hline $\mathrm{CH}-4009$ Basel & Deutschland & $\mathrm{t}: \quad+18606757834$ & $\mathrm{f}: \quad+861058771120$ \\
\hline Switzerland & $\begin{array}{l}\text { (Hausadresse: Wilhelmstrasse 20A, } \\
79098 \text { Freiburg) }\end{array}$ & $\begin{array}{l}\text { f: +18606757302 } \\
\text { e: karger@snet.net }\end{array}$ & $\begin{array}{l}\text { e: service@karger.cn; r.chew@karger.cn } \\
\text { w: www.karger.cn }\end{array}$ \\
\hline $\mathrm{t}: \quad+41613061111$ & $\mathrm{t}: \quad+49761452070$ & & \\
\hline f: +41613061234 & f: $\quad+497614520714$ & France & India, Bangladesh, Sri Lanka \\
\hline e: karger@karger.com & e: information@karger.de & Enter \& Read & Karger India \\
\hline w: www.karger.com & w: www.karger.de & Albertine Luginbuhl & Plot No. 17, Yusuf Sarai Market \\
\hline & & 23 , rue du Départ, boite 37 & B.L. Glass Building, 2nd Floor \\
\hline (for courier services only: & Japan & 75014 Paris & Sri Aurobindo Marg \\
\hline Allschwilerstrasse 10 & Karger Japan, Inc. & France & New Delhi 110016 \\
\hline CH-4055 Basel) & Shiba Daimon Asahi Bldg. $2 \mathrm{~F}$ & $\mathrm{t}: \quad+33(0) 681047685$ & India \\
\hline & 1-2-23 Shiba Daimon & e: albertineluginbuhl@orange.fr & $\mathrm{t}: \quad+911146029633$ \\
\hline & $\begin{array}{l}\text { Minato-ku } \\
\text { Tokyo } 105-0012\end{array}$ & South Fast A sia China and Taiwan & f: +911146029634 \\
\hline & $\begin{array}{l}\text { lokyo } 105-0012 \\
\text { Japan }\end{array}$ & Karger Regional Office (Malaysia) & $\begin{array}{l}\text { c: +919891052 } 128 \\
\text { e: r.kumar@kargerindia.com }\end{array}$ \\
\hline & $\mathrm{t}:+81364356242$ & CEO Suite Kuala Lumpur & w: www.karger.com \\
\hline & $\mathrm{f}:+81364356244$ & Quill 7, 27th Floor & \\
\hline & e: publisher@karger.jp & Jalan Stesen Sentral 5 & \\
\hline & w: www.karger.jp & KL Sentral & \\
\hline & & Kuala Lumpur 50470 & \\
\hline & & Malaysia & \\
\hline & & $\mathrm{f:} \quad+60327766999$ & \\
\hline & & e: service@karger.cn & \\
\hline
\end{tabular}

Change of Address:

Both old and new address should be sent

to the subscription source.

\section{KARGER}

E-Mail karger@karger.com www.karger.com
(C) 2014 S. Karger AG, Basel

The Journal Home Page is available at: www.karger.com/uin 


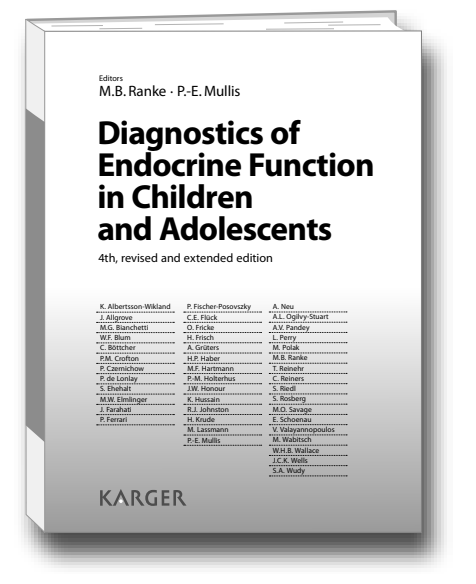

A multitude of new developments, not only in the rapidly advancing field of molecular genetics and steroid metabolism but in all traditional areas of pediatric endocrinology, have influenced the diagnostic approach in children and adolescents with endocrine disorders, thus warranting this 4 th, revised and extended edition of Diagnostics of Endocrine Function in Children and Adolescents.

Several chapters have been revised completely and all have been thoroughly updated. In addition, new chapters dealing with the muscle-bone unit and bone metabolism have also been incorporated. The original format of the chapters, which are a combination of in-depth discussion of the diagnostic process, practical conclusions and expert advice based on extensive experience, was maintained. Easy-to-use tables and figures allow for quick reference. Flowcharts of possible diagnostic pathways lead to the most frequent diagnoses.

Presenting a broad range of diagnostic approaches, test procedures, and normative data required for establishing diagnoses for a broad spectrum of endocrine disorders, this book is an indispensable reference tool not only for endocrinologists and pediatricians but also for professionals in other specialties seeking evidence-based, rapid diagnostic solutions as the basis of advice and therapy for their patients.

\section{Diagnostics of Endocrine Function in Children and Adolescents}

\author{
4th, revised and extended edition
}

\author{
Editors \\ Michael B. Ranke \\ Primus-E. Mullis
}
Contents
Preface: Ranke, M.B.; Mullis, P.-E.
Laboratory Measurements of Hormones and Related Biomarkers: Technologies, Quality Management and Validation: Elmlinger, M.W.
Molecular Genetics and Bioinformatics Methods for Diagnosis of Endocrine Disorders: Pandey, A.V.; Mullis, P.E.
Sonographic Measurement of Endocrine Tissue: Haber, H.P.; Neu, A.
In vivo Diagnostic Methods of Imaging and Tes- ting of Endocrine Function with Radionuclides: Reiners, C.; Farahati, J.; Lassmann, $M$.
Diagnostic Tests of Thyroid Function in Children and Adolescents: Krude, H.; Grüters, A. Growth Hormone Deficiency: Diagnostic Principles and Practice: Ranke, M.B.
Methods of Evaluating Spontaneous Growth Hormone Secretion: Albertsson-Wikland, K.; Rosberg, $\mathbf{S}$.
Insulin-Like Growth Factors and Their Binding Proteins: Blum, W.F.; Böttcher, C.; Wudy, S.A.
Diagnosis of Growth Hormone Excess and Hyperprolactinemia: Riedl, S.; Frisch, $\boldsymbol{H}$.
Testing Water Regulation: Czernichow, P.; Polak, M. Diagnostic Investigations in Inherited Endocrine Disorders of Sodium Regulation: Ferrari, P.; Bianchetti, M.G.
Investigation of Calcium Disorders in Children: Perry, L.; Allgrove, J.
Hyperinsulinism, Neonatal Hypoglycemia, New Mechanisms: Valayannopoulos, V.; de Lonlay, P.; Polak, $M$.
Hypoglycaemia in Infants and Children: Hussain, $\boldsymbol{K}$. Insulin Resistance in Childhood and Adolescence: Ehehalt, S.; Neu, A.
Endocrine Function of the Testis: Holterhus, P.-M.; Honour, J.W.; Savage, M.O.
Normal Ovarian Function and Assessment of Ovarian Reserve in Children and Young People: Johnston, R.J.; Wallace, W.H.B.
Assessing the Function of the Human Adrenal Cortex: Flück, C.E.
Mass Spectrometry in the Diagnosis of Steroid- Related Disorders: Clinical Applications: Wudy, S.A.; Hartmann, M.F.
Assessing Endocrine Function in the Newborn Baby: Ogilvy-Stuart, A.L.
Bone Metabolites: Crofton, P.M.
Quantification of Densitometric Bone Parameters and Muscle Function: Schoenau, E.; Fricke $\boldsymbol{O}$.
Body Composition Assessment in Children and Adolescents: Wells, J.C.K.
Effect of Body Weight on Endocrine Parameters and Fat Hormones: Wabitsch, M.; Reinehr, T.; Fischer-Posovszky, $P$.
Diagnostics: Appendix A: Ranke, M.B.
Appendix B: Ranke, M.B.
Author Index / Subject Index

www.karger.com/Diagnostics-Endo-Function

Diagnostics of Endocrine Function in Children and Adolescents

4th, revised and extended edition

Editors: Ranke, M.B. (Tübingen); Mullis, P.-E. (Bern)

XII + 536 p., 109 fig., 80 tab., hard cover, 2011 CHF 180.- / EUR 133.50 / USD 180.00

Prices subject to change

EUR price for Germany, USD price for USA only

ISBN 978-3-8055-9414-1

e-ISBN 978-3-8055-9415-8

\section{$\rightarrow$}

copy/ies

E

Postage and handling free with prepayment

Payment:

Please charge to my credit card

- $\square$ American Express $\square$ Diners

ᄂ $\square$ MasterCard $\square$ Visa

- Card No.

-

Exp. date:

- CVV/CVC

( 3 digits in the signature field on the back of Visa and MasterCard)

$\square$ Check enclosed $\square$ Please bill me

Orders may be placed with any bookshop, subscription agency, directly with the publisher or through a Karger distributor.
Fax: +41 613061234

S. Karger AG, P.O. Box, CH-4009 Basel (Switzerland)

E-Mail orders@karger.ch,www.karger.com

Name/Address: 


\section{Contents}

See the journal website for contents

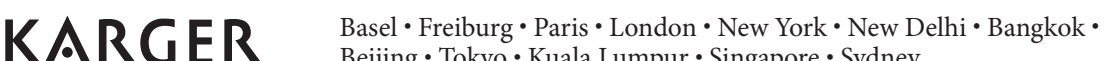
Beijing $\cdot$ Tokyo $\cdot$ Kuala Lumpur $\cdot$ Singapore $\cdot$ Sydney 


\section{Urologia Internationalis}

(Continued from back cover)

83 Single-Port Laparoscopic Retroperitoneal Surgery Using a Modified Single-Port Device in Urology

Shi, L.; Cai, W.; Dong, J.; Zhang, X.; Gao, J.; Song, T.; Sun, S.; $\mathrm{Zu}$, Q.; Wang, W. (Beijing)

89 Laparoendoscopic Single-Site Urethrovesical Anastomosis Training in an Economical Porcine Model Ni, D. (Tianjin/Beijing); Ma, X.; Li, H.Z.; Wang, B.J.; Zheng, T.; Ai, Q.; Zhang, P.; Song, E.L.; Huang, Q.B.; Gao, Y.; Zhang, X. (Beijing)

95 Clusterin Plays an Important Role in Clear Renal Cell Cancer Metastasis

Wang, X.; Luo, L.; Dong, D.; Yu, Q.; Zhao, K. (Qingdao)

104 Disruption of the Thymic Microenvironment Is Associated with Thymic Involution of Transitional Cell Cancer

Song, Y.; Yu, R.; Wang, C.; Chi, F.; Guo, Z.; Zhu, X. (Shenyang)
Case Reports

116 Advocacy for Renal Biopsy Based on Two Cases of Mixed Epithelial and Stromal Tumour

Ingels, A.; Vérine, J.; Belle Mbou, V.; Desgrandchamps, F.; Tariel, E.; Mongiat-Artus, P.; Ploussard, G. (Paris)

119 Pyocalycosis: A Report of Two Cases of Complicated Hydrocalycosis

Taşkınlar, H.; Avlan, D.; Yiğit, D.; Naycı, A. (Mersin)

122 A Case of Renal Cell Carcinoma with Inferior Vena Cava Tumor Thrombus Diagnosed during Pregnancy Katayama, H.; Ito, A.; Kakoi, N.; Shimada, S.; Saito, H.; Arai, Y. (Sendai)

124 Corrigendum 


\section{Urologia
Internationalis}

Review

1 Organic Causes of Erectile Dysfunction in Men Under 40 Ludwig, W.; Phillips, M. (Washington, D.C.)

Original Papers

7 Obesity and Prostate Cancer Incidence and Mortality: A Systematic Review of Prospective Cohort Studies Golabek, T. (Otwock); Bukowczan, J. (Middlesbrough/ Newcastle upon Tyne); Chłosta, P. (Cracow); Powroźnik, J.; Dobruch, J.; Borówka, A. (Otwock)

15 Comparison of Postoperative Infection between Robotic-Assisted Laparoscopic Prostatectomy and Open Radical Prostatectomy

Shigemura, K.; Tanaka, K.; Yamamichi, F.; Muramaki, M.; Arakawa, S.; Miyake, H.; Fujisawa, M. (Kobe)

20 Robot-Assisted Radical Prostatectomy for the Treatment of Radiation-Resistant Prostate Cancer: Surgical, Oncological and Short-Term Functional Outcomes Zugor, V. (Gronau); Labanaris, A.P. (Gronau/Thessaloniki); Porres, D.; Heidenreich, A. (Aachen); Witt, J.H. (Gronau)

27 Radical Cystectomy in the Elderly: National Trends and Disparities in Perioperative Outcomes and Quality of Care

Roghmann, F. (Montreal, Que./Herne); Sukumar, S.; Ravi, P. (Detroit, Mich.); Trinh, V.Q.; Meskawi, M. (Montreal, Que.); Ghani, K.R.; Sammon, J.D.; Friedman, A.A.; Peabody, J.O.; Menon, M. (Detroit, Mich.); Noldus, J. (Herne); Karakiewicz, P.I. (Montreal, Que./Boston, Mass.); Sun, M. (Montreal, Que.); Trinh, Q.-D. (Montreal, Que./Detroit, Mich./Boston, Mass.)

35 Introduction of an Enhanced Recovery Protocol to Reduce Short-Term Complications following Radical Cystectomy and Intestinal Urinary Diversion with Vescica Ileale Padovana Neobladder Cerruto, M.A.; De Marco, V. (Verona); D’Elia, C. (Verona/Trento); Bizzotto, L.; Curti, P.; Baldassarre, R.; Artibani, W. (Verona)
41 Fast Track Surgery to Reduce Short-Term Complications following Radical Cystectomy and Intestinal Urinary Diversion with Vescica Ileale Padovana Neobladder: Proposal for a Tailored Enhanced Recovery Protocol and Preliminary Report from a Pilot Study

Cerruto, M.A.; De Marco, V. (Verona); D’Elia, C.

(Verona/Trento); Bizzotto, L.; De Marchi, D.; Cavalleri, S.; Novella, G.; Menestrina, N.; Artibani, W. (Verona)

50 Frozen Section Analysis of Ureteral Margins in Patients Undergoing Radical Cystectomy for Bladder Cancer: Differential Impact of Carcinoma in situ in the Bladder on Reliability and Impact on Tumour Recurrence in the Upper Urinary Tract

Loeser, A.; Katzenberger, T.; Vergho, D.C.; Kocot, A.; Burger, M.; Riedmiller, H. (Wuerzburg)

55 Oncologic Outcome after Laparoscopic Radical Cystectomy without Neoadjuvant or Adjuvant Therapy with a Median Follow-Up of 32 Months

Hermans, T.J.N. (Maastricht/Veldhoven); Fossion, L.M.C.L. (Veldhoven)

64 In vivo Porcine Model for Practicing Retrograde Intrarenal Surgery

Tunc, L. (Ankara); Resorlu, B. (Canakkale); Unsal, A.; Oguz, U. (Ankara); Diri, A. (Aksaray); Gozen, A.S. (Heilbronn); Bedir, S.; Ozgok, Y. (Ankara)

68 Impact of Earlier Ureteral Ligation on Intravesical Recurrence during Hand-Assisted Retroperitoneoscopic Nephroureterectomy

Ou, C.-H.; Yang, W.-H. (Tainan)

74 Patients' Perception of Surgical Outcomes and Quality of Life after Retroperitoneoscopic and Open Pyeloplasty Khoder, W.Y.; Waidelich, R.; Becker, A.J.; Karl, A.; Haseke, N.; Bauer, R.M.; Stief, C.G. (Munich); Bachmann, A.; Ebinger Mundorff, N. (Basel)

(Continued on inside back cover)
Cover illustration

A schematic diagram showed how to avoid the damage of surrounding structures and entry directly into the fornix of the target calyx. Wang, Y. et al., Vol. 91, No. 3, p. 327. 